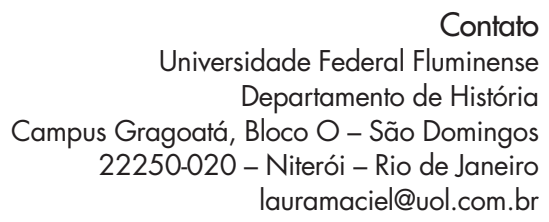

Contato

Universidade Federal Fluminense Departamento de História Campus Gragoatá, Bloco O - São Domingos 22250-020 - Niterói - Rio de Janeiro lauramaciel@uol.com.br

\section{IMPRENSA, ESFERA PÚBLICA E MEMÓRIA OPERÁRIA - RIO DE JANEIRO $(1880-1920)^{*}$}

\author{
Laura Antunes Maciel**
}

Universidade Federal Fluminense

Niterói - Rio de Janeiro - Brasil

\title{
Resumo
}

A experiência de trabalhadores com a imprensa na cidade do Rio de Janeiro constitui-se no interior do movimento de ampliação da cultura letrada, dos circuitos de comunicação social e das tensões que marcaram esse processo na passagem do século XIX para o XX. Este artigo mapeia a distribuição espacial desses periódicos e suas redações e analisa a atuação dos mesmos como espaços de organização e afirmação da presença pública dos trabalhadores na cidade. Destaca, no interior dessa imprensa, as iniciativas voltadas para a produção e coleta de testemunhos históricos procurando compreendê-las como estratégias de afirmação de identidades operárias e de legitimação de suas memórias e histórias.

\section{Palavras-chave}

Imprensa operária - comunicação social - cultura letrada.

* Este texto é resultado de pesquisa em andamento financiada com bolsas de iniciação científica do Conselho Nacional de Desenvolvimento Científico e Tecnológico - CNPq e Fundação de Amparo à Pesquisa do Estado do Rio de Janeiro - Faperj. Agradeço aos pareceristas ad hoc pelas sugestões e contribuições ao texto.

** Doutora em História Social pela Pontifícia Universidade Católica de São Paulo - PUC/SP. Professora de História do Brasil no Instituto de História da Universidade Federal Fluminense. 


\section{Laura Antunes Maciel}

Universidade Federal Fluminense

Niterói - Rio de Janeiro - Brasil

\begin{abstract}
In the late nineteenth century to the twentieth, at Rio de Janeiro, the experience of working with the press occurs in the movement of expansion of literacy in the media circuit, with obvious tensions that have marked this process. This article covers the spatial distribution of those newspapers and its newsrooms and thus analyzes the performance thereof as an organization of spaces and public affirmation of the presence of workers in the city. This work also highlights the initiatives for the production and collection of historical evidence within this press, trying to understand it as affirmation strategies of workers' identities and legitimizing their memories and stories.
\end{abstract}

\title{
Keywords
}

Labor press - media - literacy. 
Capital do Império e depois da República, principal porto, centro financeiro, político e administrativo do país, o Rio de Janeiro passou por profundas mudanças sociais, econômicas e culturais, mantendo posição de destaque na vida pública brasileira ao longo do século XIX e grande parte do XX. Estudos diversos demonstraram a magnitude dessas alterações, principalmente na composição social da sua população, e a complexidade das relações e práticas sociais que aproximavam e opunham trabalhadores, escravizados ou livres, imigrantes ou nacionais, participantes ou não de movimentos políticos e sociais organizados, atuando em múltiplos ofícios com níveis diversos de especialização. ${ }^{1}$ No Rio de Janeiro de 1852 "64,5\% dos trabalhadores empregados nos 1.013 estabelecimentos artesanais e industriais (...) eram escravos e os outros 35,5\% eram trabalhadores livres, brasileiros e estrangeiros". Vinte anos mais tarde, quando foi realizado o primeiro censo nacional, os habitantes da cidade somavam 270.000 pessoas e "os escravos eram apenas 10,2\% dos artesãos e operários da cidade, enquanto os nacionais livres eram 49,0\% e os estrangeiros 40,6\%". ${ }^{2}$

Maior cidade brasileira em 1890, o Distrito Federal possuía 522.651 habitantes concentrando o maior contingente de negros e mulatos de todo o Sudeste brasileiro - cerca de 180 mil ou 34\% da população. Reunia também um número expressivo de imigrantes pobres - 155.202 mil estrangeiros dos quais 106.461 eram portugueses -, a metade deles havia chegado à cidade ao longo da década de $1880 .{ }^{3}$ Compartilharam experiências das lutas sociais pela abolição da escravidão e a redefinição nas relações de trabalho, das mobilizações em prol do direito à livre organização, criação de formas associativas e espaços de sociabilidade, além das tentativas de unificar ações, reivindicações e protestos de trabalhadores na cidade. Heterogêneos em termos étnicos, culturais e nas suas formas de inserção no mundo do trabalho, os trabalhadores cariocas viviam às voltas com um mercado de trabalho competitivo e disputado, que mantinha desempregados ou subempregados

\footnotetext{
1 CHAlHOUB, Sidney. Visões da liberdade: uma história das últimas décadas da escravidão na Corte. São Paulo: Cia. das Letras, 1990; GRAHAM, Sandra L. O panorama social da casa e da rua. In: Idem. Proteção e obediência. Criadas e seus patrões no Rio de Janeiro, 1860-1910. São Paulo: Cia. das Letras, 1992; LARA, Sílvia Hunold. Escravidão, cidadania e história do trabalho no Brasil. Projeto História, no 16. São Paulo: PUC/SP, fev. 1998; MATTOS, Marcelo Badaró. Trabalho, vida urbana e experiência de exploração. In: Idem. Escravizados e livres. Experiências comuns na formação da classe trabalhadora carioca. Rio de Janeiro: Bom Texto, 2008.

2 CHALHOUB, Sidney. Visões da liberdade, op. cit., p. 200.

3 CHALHOUB, Sidney. Trabalho, lar e botequim. O cotidiano dos trabalhadores no Rio de Janeiro da Belle Èpoque. $2^{\text {a }}$ edição. Campinas: Ed. da Unicamp, 2001, p. 43-44.
} 
50\% da população economicamente ativa no final dos anos $1880,{ }^{4}$ enfrentavam longas jornadas e baixos salários, além de terem que lidar com a rigidez de normas e regulamentos no trabalho em oficinas e fábricas que visavam cercear sua liberdade de ação e organização.

Não é de estranhar, portanto, os frequentes comentários de lideranças e militantes sobre as dificuldades para construir uma unidade de pensamento e ação política entre os trabalhadores cariocas. Divididos em múltiplas formas de organização e luta, criadas a partir de meados do século XIX, possuíam orientações políticas plurais que sustentavam práticas sindicais "idênticas ou muito semelhantes", incluindo perspectivas reformistas diversas "desde o socialismo reformista ao mais estreito trade-unionismo, passando por correntes que se arvoravam republicanas sociais ou corporativistas", ${ }^{5}$ até o anarquismo revolucionário. Foi no interior dessas diferenças que os trabalhadores cariocas constituíram sua militância por meio do periodismo, uma experiência social extremamente importante e compartilhada pela maioria das categorias e organizações. Sem dúvida, a propaganda organizada e metódica por meio da imprensa foi uma estratégia de luta prioritária definida por sindicatos, ligas e sociedades de resistência criados por trabalhadores no Rio de Janeiro a partir de meados do século XIX, seguida pela impressão e distribuição de folhetos, cartazes, "as conferências, excursões de propaganda, representações teatrais e criação de bibliotecas". ${ }^{6}$

Em 1913, representantes das associações reunidos no Segundo Congresso Operário ampliaram o debate em torno da "conveniência da disseminação da imprensa operária", das formas de sustentação e financiamento de seus jornais e revistas e a admissão, ou não, de jornalistas profissionais "no meio operário". Considerando que "é pela imprensa que a classe capitalista firma a opinião pública em favor de seus interesses e das suas infames aspirações" e que "todas as [suas] torpes artimanhas e mistificações" [eram] "habilmente alinhavadas por profissionais da pena, que dela fazem comércio", os delegados participantes naquele congresso decidiram que, "em face desta imprensa comercial", as sociedades e sindicatos operários e os trabalhadores em geral deveriam se empenhar em criar "jornais de propaganda integralmente eman-

4 DAMAZIO, Sylvia. Retrato social do Rio de Janeiro na virada do século. Rio de Janeiro: EdUERJ, 1996, p. 39. BATALHA, Cláudio Henrique de Moraes. Uma outra consciência de classe? O sindicalismo reformista na Primeira República. Ciências Sociais hoje. In: Anuário de Antropologia, Política e Sociologia. São Paulo: Vértice/Anpocs, 1990, p. 5.

6 Confederação Operária Brasileira. Resoluções do Primeiro Congresso Operário Brasileiro. Rio de Janeiro: Vilas-Boas, 1906, p. 79. 
cipadora" além de auxiliar os já existentes, e os que viessem a existir, de modo a formar nos trabalhadores "a verdadeira consciência e sólidas convicções".

O número e a diversidade de periódicos localizados em arquivos e bibliotecas no Rio de Janeiro oferecem evidências significativas da grande adesão de trabalhadores a essas teses e da importância atribuída à palavra impressa para sua emancipação social e política. O reconhecimento dos periódicos mantidos por associações, partidos e grupos de trabalhadores revela uma significativa diversidade de sujeitos envolvidos com a redação, edição e distribuição de uma profusão de títulos e formatos que, em sua maioria, constituem coleções reduzidas, às vezes em precárias condições de preservação e acesso, sem referências documentais consolidadas. ${ }^{8}$ Constituem testemunhos importantes dos projetos e lutas de trabalhadores e, também, de suas opiniões e intervenções sobre as questões sociais mais amplas que os mobilizaram naquelas conjunturas. Gostaria de retomar neste artigo algumas questões em torno das múltiplas experiências de trabalhadores cariocas com o periodismo, um tema frequentemente mencionado, mas pouco analisado. Procuro relativizar análises que, ainda hoje, sustentam a existência de um iletramento generalizado entre os trabalhadores e de sua ausência nas lutas pela expansão da educação e dos circuitos da cultura letrada. Continuamente repetido e reelaborado, o argumento da escassez - ou ausência - de documentos textuais produzidos diretamente por trabalhadores que possam ser transformados em fontes de informações históricas tem justificado

\footnotetext{
7 Resoluções do Segundo Congresso Operário Brasileiro. In: RODRIGUES, Edgar. Alvorada operária. Rio de Janeiro: Mundo Livre, 1979, p. 137-8.

8 Os fichários e catálogos das instituições de pesquisa utilizam diferentes classificações e descritores para organizar as referências documentais sobre a imprensa operária, separando os títulos em função da origem étnica ou nacional dos responsáveis pela edição, das orientações políticas do periódico, do tipo de publicação ou, ainda, dos setores onde as coleções estão armazenadas. Essas operações dificultam a compreensão da abrangência social desse periodismo, suas articulações e dissensos internos. As reflexões apresentadas neste texto tomam por base a análise das coleções de 70 títulos de periódicos publicados por trabalhadores na cidade do Rio de Janeiro, localizados até o momento no acervo da Biblioteca Nacional. No entanto, esse universo pode ser maior considerando que as buscas precisam combinar diferentes palavras-chave - operários [69 títulos], proletariado [16 títulos], trabalhadores [25 títulos], trabalhista [16 títulos], além de descritores genéricos como impressão, imigração e trabalho. Outros pesquisadores, utilizando acervos e instituições diferentes, com outros recortes temporais e metodologias, produziram resultados diversos. Ver, por exemplo: KOCHER, Bernardo; LOBO, Eulalia Maria Lahmeyer; MARTINS, Ismênia de Lima. Guia dos jornais operários do Rio de Janeiro. Rio de Janeiro: Universidade Federal Fluminense, 1988 [93 títulos inventariados para o período 1858-1930] e FERREIRA, Maria Nazareth. Imprensa operária no Brasil. São Paulo: Editora Ática, 1988 [185 títulos inventariados para o período 1847-1930].
} 
e legitimado, ainda hoje, a impossibilidade de construir narrativas e explicações históricas a partir de suas próprias perspectivas e pontos de vista. Justifica-se, dessa forma, a exclusão da maioria da população da história, em particular, daquela parcela que permaneceu à margem de movimentos e lutas sociais, ou que não possuía qualquer vínculo sindical.

Em geral, os pesquisadores recorrem à imprensa operária apenas como "fontes" de informações sobre condições de vida e trabalho, formas de organização e ações coletivas, sem analisar as especificidades do jornalismo desenvolvido por trabalhadores. Outros privilegiaram a ação de indivíduos e grupos mais atuantes na imprensa, como alguns intelectuais anarquistas que se destacaram como criadores ou colaboradores de vários periódicos; ou, ainda, destacaram a ação de algumas categorias profissionais, como os tipógrafos e gráficos, cujo domínio da leitura e da escrita, além de habilidades de composição e impressão, os tornava mais aptos ao exercício do jornalismo. Mas, em geral, investiram pouco no reconhecimento do jornalismo praticado por um conjunto mais amplo de operários qualificados ou artesãos, empregados em fábricas e oficinas ou trabalhando por conta própria - sapateiros, barbeiros, marmoristas, trabalhadores em pedreiras e na construção civil, motoristas, estivadores e padeiros - que, embora exercessem ofícios para os quais não se exigia o domínio da leitura e da escrita, estavam profundamente envolvidos com a cultura letrada e a publicação de periódicos. ${ }^{9}$

Ainda conhecemos pouco o processo de ampliação e diversificação da imprensa operária, para além de sua vertente militante, assim como as transformações no formato, linguagens e modos de informar e opinar, resultantes do intenso, e tenso, diálogo com a publicidade, a caricatura, o humor e

\footnotetext{
9 Esta investigação procura reconhecer a pluralidade da imprensa produzida por trabalhadores, abarcando periódicos empenhados na organização da classe trabalhadora, na reivindicação de direitos ou na militância política, tanto aquela publicada por associações (que agregavam por ofícios ou atividades profissionais ou se assumiam como órgãos de classe) quanto por grupos de trabalhadores. Os títulos arrolados a seguir indicam a pluralidade desse universo reconhecido como "imprensa operária": A Voz do Padeiro (1913); A Voz do Marmorista (1903); Boletim do Centro dos Operários Marmoristas (1925); Voz do Chauffer: Notícias - crítica - literatura \& arte (1924-1926); O Alfaiate (1903-6); O Echo do Mar: Propriedade das associações de marinheiros e remadores e da União dos Foguistas (1909); O Sapateiro (1928); O Barbeiro (1926); Brazil Operário: Órgão das classes proletárias (1903-4); Gazeta Operaria (1902-6); Voz do Povo: Órgão da Federação dos Trabalhadores do Rio de Janeiro e do proletariado em geral (1920). Sobre a expansão e transformação da imprensa operária, suas linguagens, grupos editores e leitores ver MACIEL, Laura Antunes. Imprensa de trabalhadores, feita por trabalhadores, para trabalhadores? História E Perspectivas, n. 39, Uberlândia: UFU, 2008.
} 
o periodismo de variedades, a partir das duas décadas finais do século XIX.10 A partir dessas décadas, novos sujeitos coletivos se constituíram e ganharam visibilidade na cidade do Rio de Janeiro por meio da imprensa, reivindicando direitos sociais, divulgando propostas políticas diversas, realizando a crítica de ideias, argumentos e opiniões, enfim questionando o monopólio de classe sobre a opinião pública. Portanto, para uma compreensão renovada das tensões sociais que marcam a história da imprensa operária ela precisa ser analisada não apenas no bojo do enfrentamento classista com a "imprensa comercial" ou burguesa, mas, também, em face da expansão da vida associativa na cidade, como "espaços que articulam vivências coletivas não só da elite masculina, mas de setores sociais bastante diversificados", além do crescente letramento da população e ampliação da "rede potencial de leitores".11

Outro aspecto a assinalar é que os periódicos classificados nos acervos e instrumentos de pesquisa como "imprensa operária" remetem para uma gama variada de publicações (sindicais, partidárias, de associações culturais e profissionais etc.), pouco ou nada homogênea em termos de sua constituição, conteúdos ou objetivos, apesar de compartilharem alguns aspectos que as diferenciam de outras modalidades de periodismo. Sua propriedade estava em mãos de associações ou de grupos isolados de trabalhadores que se dedicavam a debater seus problemas e questões; eles exerciam um jornalismo autônomo, independente, crítico e socialmente posicionado; constituíam os trabalhadores como protagonistas pois eram, ao mesmo tempo, "jornalistas, fontes, conteúdos e destinatários dos textos".12

Se os subtítulos de alguns jornais sinalizam pretensões de articular e representar categorias profissionais específicas - como "a classe gráfica", "os empregados do comércio" ou "os caixeiros", "operários chapeleiros", "empre-

\footnotetext{
${ }^{10}$ CRUZ, Heloisa de Faria. São Paulo em papel e tinta: periodismo e vida urbana - 1890-1915. São Paulo: Educ/ Fapesp/ Arquivo do Estado de São Paulo/ Imprensa Oficial de São Paulo, 2000, p. 66-67. HARDMAN, Francisco Foot. Imprensa operária, espaço público e resistência: notas de leitura. In: Idem. Nem pátria, nem patrão. $3^{\mathrm{a}}$ edição [1 ${ }^{\mathrm{a}}$ edição: 1983]. São Paulo: Ed. da Unesp, 2002.

${ }^{11}$ CRUZ, Heloisa de Faria. São Paulo em papel e tinta, op. cit., p. 66. Para uma análise sobre a importância da imprensa na articulação de lutas sociais nos subúrbios cariocas ver MENDONÇA, Leandro Clímaco. Nas margens: experiências de suburbanos com periodismo no Rio de Janeiro, 1880-1920. Niterói: Ed da UFF, 2014.

${ }^{12}$ KUCINSKI, Bernardo. A síndrome da antena parabólica. Ética no jornalismo brasileiro. São Paulo: Editora Fundação Perseu Abramo, 1998, p. 26. Ferreira indica as dificuldades para a conceituação da imprensa operária e destaca os seguintes aspectos: os veículos não tinham proprietário, sua mensagem não era uma mercadoria a ser consumida e o seu conteúdo era produzido pela coletividade de trabalhadores e destinava-se a ela mesma. FERREIRA, Maria Nazareth. A imprensa operária no Brasil. Petrópolis: Vozes, 1978, p. 6.
} 
gados de padaria" ou os "operários marmoristas" -, outros se dirigiam a todos os sócios de uma associação beneficente ou grêmio cultural de caráter e objetivos diversos. Existiram também periódicos que se apresentavam como representantes de todos os trabalhadores, órgãos das "classes proletárias", "do operariado", "defensor de todas as classes" e "do povo em geral", além daqueles que indicam a busca de independência - crítica, liberdade, resistência ou combate. As coleções desses periódicos fornecem pistas de rumos sociais diversos não só na expansão dos públicos leitores na cidade como da atuação dessa imprensa para a constituição de outras formas de unidade ou identidade, agregando diferentes grupos de trabalhadores e múltiplos interesses sociais.

A palavra impressa constituiu-se como uma arma poderosa manejada por trabalhadores para combater os "valores e opiniões burgueses" que se pretendiam universais e para o embate pela sua afirmação pública na cidade. São inúmeras as evidências que indicam tentativas de intervir na redefinição da agenda política da cidade e, também, de enfrentar, com todos os seus limites e percalços, lutas diversas contra a opressão: entre trabalhadores e patrões, entre cidadãos e governantes, entre direções e as bases do movimento organizado, que podem ser lidos como esforços para a criação de uma esfera pública diferenciada.

A importância atribuída à imprensa como instrumento para a construção não apenas de uma identidade comum, mas da respeitabilidade pública para os trabalhadores, além do poder que o conhecimento, a cultura impressa e a escrita representavam na formação de uma consciência de classe, foi compartilhada - em maior ou menor grau - pelo conjunto dos trabalhadores cariocas. Mas o significado dessas escolhas também precisa ser avaliado no interior das tensões e disputas em torno dos novos instrumentos legais que definiram a capacidade de ler e escrever como condições para aquisição ou exclusão de direitos políticos em finais do século XIX.

\section{A imprensa trabalhadora: motivações e significados}

Reconhecer a ação organizada de trabalhadores por meio da imprensa possibilita acompanhar parte de uma luta mais ampla travada no Rio de Janeiro em prol da ampliação e deslocamento do significado liberal atribuído à cidadania (como o direito à representação pelo voto e às garantias e liberdades civis). Uma leitura atenta dessa imprensa traz evidências de que ela se 
constituía com o propósito de ensinar a "pensar e julgar as coisas e os atos"13 e, também, para a formulação, expressão e reivindicação de novos direitos. Afinal, a imprensa deveria ser avaliada "não pelo importe das suas assinaturas, mas pelo número de direitos alcançados, de preconceitos banidos, de abusos esmagados", como alguém argumentou nas páginas de $O$ Domingo, órgão dos trabalhadores no comércio, em julho de $1878 .{ }^{14}$

Nessa direção, uma primeira questão a ser esclarecida são as motivações que animaram trabalhadores a criar periódicos e a mantê-los como espaços públicos - de debate, questionamento e crítica - em uma sociedade "cuja experiência ampliada de participação civil inexiste e cuja noção de negociação política era [e ainda é] extremamente excludente" ${ }^{15}$ Em que medida e por quais vias foi possível, para os trabalhadores cariocas do passado, criar seus próprios lugares de ação e representação em uma sociedade que buscava reduzi-los ou à condição de "um povo imaturo, sem integração entre si e com o resto da sociedade, sem vocação para a universalidade e incapaz de solidariedade e de ação coletiva", ou associá-los ao "perigo (...) quando, em seu protesto, formam a 'ralé' e a 'populaça' sem raízes culturais onde ancorar alguma legitimidade" ?"16

A linguagem pesada frequentemente usada para combater essa imprensa - "pasquins", "jornaizinhos" ou "jornalecos" "virulentos e violentos", "subliteratura" subversiva -, produzida fora dos círculos restritos do poder ou dos letrados, sugere que algumas dessas folhas conseguiram se constituir como vozes dissidentes que desafiavam os consensos naquela sociedade e, usando da palavra impressa, tentaram conferir legitimidade às suas ações e interesses.

Incluir-se e manter-se nesse espaço público restrito significou, muitas vezes, vencer o descrédito ou a resistência dos próprios companheiros; disputar leitores com os poderosos jornais diários; superar dificuldades de financiamento e distribuição; além de driblar ameaças de empastelamento, censura e outras formas de repressão frequentemente acionadas pelos patrões e pela polícia. Acompanhar algumas das exigências legais para a

\footnotetext{
${ }^{13}$ Na luta. O Baluarte, n. 1. Órgão dos operários chapeleiros. Rio de Janeiro, ano I, maio de 1910, p. 1. Publicado por subscrição voluntária sob a direção de José Sarmento Marquez.

${ }^{14} \mathrm{O}$ Sapucaiense. $O$ Domingo, n. 26. Órgão dos empregados do comércio. Rio de Janeiro, ano I, de 14 de julho de 1878, p. 2. Publicado entre 1878-9, tinha como editor S. R. Chaves.

${ }^{15}$ PAOLI, Maria Célia. Trabalhadores e cidadania: Experiência do mundo público na história do Brasil moderno. Estudos Avançados, vol. 3, n. 7, São Paulo: Instituto de Estudos Avançados da Universidade de São Paulo, set.-dez. 1989, p. 44.

${ }^{16}$ PAOLI, Maria Célia. Trabalhadores e cidadania, op. cit., p. 45.
} 
criação de jornais por entidades de classe, o policiamento ostensivo às redações e aos jornalistas-trabalhadores, as normas jurídicas visando regular o exercício do direito à livre expressão [assim como à livre organização] podem indicar caminhos para compreender reações à ampliação dos espaços de crítica social naquela conjuntura.

É significativo que o parlamentar paulista Adolfo Gordo, autor dos projetos de leis para expulsão de estrangeiros aprovadas em 1907 e 1913, utilizadas para reprimir a organização autônoma de trabalhadores, tenha sido também o relator no Senado, em 1923, de uma lei para regular a atuação da imprensa operária exatamente em um momento de ascensão da organização e conquistas dos trabalhadores. ${ }^{17}$ Apesar de ter entrado para a história como a "primeira lei de imprensa" brasileira, seu alvo era muito claro: o cerceamento legal dos direitos de trabalhadores à ação organizada e à livre expressão de suas ideias e opiniões por meio da imprensa, permitindo à ação policial fechar associações, sindicatos, redações e oficinas impressoras mantidos por trabalhadores, além da repressão e prisões contra redatores e gráficos de vários jornais operários.

Dois anos antes, o esforço para conter o movimento operário já havia se tornado explícito com a aprovação de um conjunto de normas para "repressão ao anarquismo", incluindo o controle sobre a imprensa e organizações de trabalhadores supostamente envolvidos em atos considerados "nocivos ao bem público" ou que defendessem a "subversão da atual organização social".18 São evidências que permitem ampliar a reflexão para além da sempre autoproclamada agressão à "liberdade de imprensa" formulada em termos liberais e que nomeia os agredidos em função desses mesmos pressupostos. O reconhecimento de alguns direitos sociais aos trabalhadores - livre associação, expressão e exercício de greves - foi um processo lento e que

\footnotetext{
${ }^{17}$ Decreto n. 4.743, de 31 de outubro de 1923. Regula a liberdade de imprensa e dá outras providências. Disponível em: http://www6.senado.gov.br/legislacao/ListaPublicacoes.action?id=46243. Acesso em: 30/11/2015. Além de caracterizar os crimes de imprensa, instituir a censura prévia e criar a responsabilidade solidária, definiu prisão especial para os jornalistas "infratores", as responsabilidades, penas e o processo.

${ }^{18}$ Decreto n. 4.269, de 17 de janeiro de 1921. Regula a repressão do anarchismo. Disponível em: http://www6.senado.gov.br/legislacao/ListaPublicacoes.action?id=44625. Acesso em: 30/11/2015. Este decreto ampliou e revigorou a criminalização de dirigentes nacionais do movimento de trabalhadores iniciado com os decretos n. 1.162, de 12 de dezembro de 1890, que suspendeu a proibição de greve, mas limitou seu exercício, prevendo punições para "violências" e "excessos", e o de n. 6.994, de 19 de junho de 1908, que possibilitou enquadrar militantes como "agitadores", "desordeiros" e "indesejáveis", sujeitos a penas de prisão.
} 
historicamente oscilou entre a proibição, a concessão de liberdade controlada para exercê-los, até sua aceitação como um direito nos anos 1940, porém acompanhada de normas que, em diferentes momentos e de modos diversos, criminalizaram essas práticas.

Em uma sociedade que se caracterizava pela exclusão política extrema, “a não sujeição ao consenso é considerada subversiva e ilegítima" e justificou, em diversos momentos, medidas de força para o cerceamento às pequenas e combativas folhas editadas por trabalhadores tentando impedir o exercício de sua expressão política. Enquanto a chamada grande imprensa nasceu elitista, e ainda se mantém assim 200 anos depois, já que "a elite dominante é ao mesmo tempo a fonte, a protagonista e a leitora das notícias", algumas iniciativas de trabalhadores com a imprensa desafiaram essa "circularidade que exclui a massa da população da dimensão escrita do espaço público".19 Nesse sentido, as múltiplas e diversas iniciativas populares para criar e manter uma imprensa capaz de constituir a massa como sujeito coletivo e ativo - e também como protagonista social, fonte de informações e leitora -, não são [e não foram] tarefas fáceis; ainda mais em uma sociedade recém saída da escravidão, com senhores pouco afeitos ao debate e à escuta do outro.

Por essa razão, ganha maior relevância conhecer as razões que levaram trabalhadores a travar suas lutas no mesmo terreno e com as mesmas armas escolhidas por seus oponentes: os periódicos e a palavra impressa. Muitos desses jornais afirmavam agir orientados por razões semelhantes àquelas que motivaram Lima Barreto a escrever suas recordações (ou de Isaías Caminha?). Em vez de ter acessos de ódio e rasgar as páginas de revistas e jornais que frequentemente publicavam "multiplicadas considerações desfavoráveis à natureza da inteligência das pessoas do meu nascimento", o escritor ponderou que "verrinas nada adiantam, não destroem; se, acaso, conseguem afugentar, magoar o adversário, os argumentos deste ficam vivos, de pé". Por isso, o melhor caminho "seria opor argumentos a argumentos, pois se uns não destruíssem os outros, ficariam ambos face a face, à mão de adeptos de um e de outro partido". ${ }^{20}$

Os expedientes das folhas mantidas por trabalhadores registram explicações e intenções semelhantes: produzir argumentos para fazer "pensar com independência". Os marinheiros, remadores e foguistas articulados em

\footnotetext{
${ }^{19}$ KUCINSKI, Bernardo. A síndrome da antena parabólica, op. cit., p. 19- 22.

${ }^{20}$ BARRETO, Lima. Breve notícia. In: Recordações do escrivão Isaías Caminha. São Paulo: Ática, 1995 [1 ${ }^{\text {a }}$ edição Garnier, 1909], p. 11.
} 
torno d'O Echo do Mar, o "órgão defensor dos direitos e interesses das classes marítimas inferiores", definiram como seu objetivo "doutrinar as classes marítimas inferiores, para propugnar pelos seus direitos e pelos seus interesses"; os empregados do comércio organizados para a criação d'O Caixeiro visavam constituir uma "tribuna onde [poderiam] defender os seus direitos"; chapeleiros visavam franquear as páginas d'O Baluarte a todos os companheiros que desejassem "propagar a reivindicação dos trabalhadores" enquanto os trabalhadores em pedras e cantaria propunham organizar "os espíritos para a luta" através do seu órgão $O$ Marmorista; trabalhadores em padarias lançaram $O$ Panificador para defender "os nossos interesses, salvaguardando a nossa dignidade, e atacando energicamente aqueles que menosprezam os [nossos] direitos"; os que militavam na Associação Gráfica propunham que $O$ Grafico fosse um "apaixonado defensor do direito à justiça, do companheiro vitima da prepotência e da exploração gananciosa dos que impondo deveres negamnos a defesa, desse direito, como homens produtores"; o cigarreiro socialista Mariano Garcia e demais companheiros fundadores da Gazeta Operária, pretendiam "franquear as suas colunas a todos os propagandistas emancipados e conscientes de que o nosso caminhar só pode ser para o socialismo" ao mesmo tempo que iriam "advogar os interesses das classes trabalhadoras". ${ }^{21}$

Poderia reproduzir muitas outras opiniões semelhantes, porém é preciso ir adiante para avaliar se, e em que medida, alguns desses jornais populares se afirmaram como lugar do dissenso e de crítica. Nesse sentido, um caminho em aberto é a leitura dessas pequenas e combativas folhas para evidenciar aquelas que buscaram elaborar uma percepção própria e popular da política e da sociedade. Quais delas pretenderam, ou conseguiram, "reger seu presente" de forma autônoma, como defendiam trabalhadores do comércio em O Caixeiro em 1881? A análise da intensa atuação de trabalhadores por meio de folhas periódicas pode nos indicar caminhos possíveis para a construção de uma esfera pública em uma sociedade que recém abolira a escravidão e pouco afeita aos valores democráticos, na qual o controle sobre o letramento e a imprensa funcionaram como sólidos obstáculos à ampliação de direitos, dentre eles o de debater, expressar e canalizar opiniões e reivindicações.

Ao investir na criação de jornais para expressar e debater ideias, valores, projetos e reivindicações, trabalhadores se constituíam como sujeitos de ação coletiva capazes de fundar espaços de atuação pública por meio da

\footnotetext{
${ }^{21}$ Gazeta Operária, n. 1. Rio de Janeiro, ano I, 28 de setembro de 1902, p. 1. Dirigido por Mariano Garcia tinha redação na rua Barão de S. Felix, 163, e foi publicado entre 1902-3.
} 
palavra impressa. A leitura desses jornais traz ecos de outras lutas sociais conduzidas por trabalhadores - contra a carestia, repudiando o militarismo e o alistamento obrigatório, condenando a guerra e defendendo o pacifismo, reivindicando a ampliação da instrução pública e o direito de voto. Agitando e defendendo valores mais amplos do que os seus interesses classistas imediatos - o direito ao trabalho, à remuneração digna, à livre associação e expressão, entre outros -, buscaram por meio de seus periódicos constituir novas estratégias de luta para conquistá-los.

A atuação por meio de jornais não indica o reconhecimento da palavra impressa como campo privilegiado de embate e de ampliação de suas forças? Ao investir na criação e manutenção de folhas diversas e plurais não estariam constituindo novas formas de inserção social e política assim como produzindo outro horizonte de possibilidades interpretativas para suas próprias vidas, interesses e projetos? A publicação recorrente de artigos, poemas, convocações para reuniões, atas e relatórios de assembleias, informes de greves, não podem ser interpretados como parte de um esforço mais amplo para elaborar "a categoria de dignidade como o centro da condição proletária e, através dela, costurar os traços comuns"22 entre companheiros de um mesmo ofício, e destes com outros trabalhadores?

Ou, ainda, em que medida jornais com opções ideológicas diversas e graus diferentes de engajamento no movimento operário se constituíram como instrumentos para formular e construir coletivamente o reconhecimento social e público da sua condição comum de trabalhadores? Alguns deles se empenharam para formular a compreensão de um "nós" que congregaria "todos os operários, sejam de que classe forem" que, aos poucos, tomavam consciência e alegavam "motivos que essa gente [industriais e jornalistas] nunca acha que sejam justos", como afirmou um marmorista nas páginas de seu órgão de classe. ${ }^{23}$

Numa sociedade "onde o campo de luta principal parece ser o dos direitos de reconhecimento, representação e negociação dos trabalhadores como classe, cujas alternativas institucionais de controle e de consenso têm que se dar sobre uma outra figuração da vida popular e de sua presença", ${ }^{24}$ o prota-

\footnotetext{
${ }^{22}$ PAOLI, Maria Célia. Trabalhadores e cidadania, op. cit., p. 48.

${ }^{23}$ O Marmorista. Órgão de propaganda dos operários marmoristas. Rio de Janeiro, 1 de janeiro de 1907, p. 2. O jornal era publicado mensalmente por subscrição voluntária e administrado por João Arzua dos Santos, presidente do Centro dos Operários Marmoristas.

${ }^{24}$ PAOLI, Maria Célia. Trabalhadores e cidadania, op. cit., p. 48-49.
} 
gonismo de trabalhadores na criação e manutenção de jornais pode indicar alguns dos percursos (e os muitos entraves) à constituição de um espaço de negociação política entre trabalhadores, patrões e o Estado. É bem verdade que localizamos críticas a trabalhadores que, em vez de orientar os companheiros, exploravam "opiniões, preparando terreno para serem jornalistas e propagandistas, e merecendo o elogio da burguesia, representada pela grande imprensa, que acata a sua ação por não atacar diretamente o capitalismo". ${ }^{25}$

Nesse sentido, podemos compreender a reconhecida militância em periódicos como tentativa de criação de outros canais de ação, negociação e pressão política - ao lado de greves, piquetes, comícios e outras formas de lutas - mas, também, para encaminhar reivindicações mais amplas em prol da ampliação da participação popular na vida pública naquele período. Os jornais trazem evidências de múltiplas apostas de trabalhadores para constituir um canal de representação pública autônoma; para formular temas e bandeiras próprias e para elaborar uma linguagem comum. A militância no jornalismo e por meio dele constituiu-se como uma das opções de auto-organização e formação de um movimento autônomo de trabalhadores, pelo menos para aqueles que mantiveram uma prática próxima do cotidiano das categorias que buscavam representar.

\section{Entre presente e passado: marcos e interpretações históricos}

As memórias de antigos militantes revelam a importância desses jornais tanto como instrumento de propaganda e união de trabalhadores nas primeiras décadas do século XX quanto para reavivar lembranças ou como testemunho e esteio para a interpretação do passado vivido. Everardo Dias, nascido em 1883 e um trabalhador gráfico atuante no movimento operário, abre seu livro de memórias com as seguintes palavras:

Estamos escrevendo estas linhas no $1^{\circ}$ de maio de 1961. Sessenta anos são passados desde que iniciamos (...) a nossa vida de prosélito e de agitador, de ouvinte ávido e mais tarde de lutador, escrevendo, falando, dissertando em conferências e meetings. (...) Foi a época ou período da propaganda mais ou menos contínua e densa, por meio de jornais, de folhetos, de festivais, de conferências, de comemorações. ${ }^{26}$

\footnotetext{
${ }^{25}$ O Marmorista. Rio de Janeiro, 1 de janeiro de 1907. Texto assinado por M. D. d'Almeida, com data de 23 de dezembro de 1906, publicado na seção "Movimento Operário".

${ }^{26}$ DIAS, Everardo. História das lutas sociais no Brasil. São Paulo: Editora Alfa-Omega, 1977, p. 19-20.
} 
Mais de uma década depois, Octávio Brandão, militante anarquista e comunista nascido em 1896, ao ser chamado a lembrar sua atuação nas atividades sindicais cariocas destacou a importância dessa imprensa como fonte de informações históricas e instrumento para ativar sua própria memória:

M. C. - Agora, Otávio, eu gostaria que você me contasse a greve da Leopoldina de 1920, de março de 1920. O que ocasionou a greve?

O. B. - Bem, eu tenho um estudo sobre isso. (...). Mas na cabeça não, não deu. Fui à Biblioteca Nacional. Tem lá uma coleção da Voz do Povo. Eu abri na hora, "Greve da Leopoldina", e reconstituí aquilo tudo. Mas de memória, eu não me lembro. ${ }^{27}$

A pesquisa nas seções, colunas e conteúdos abordados em periódicos de trabalhadores sem dúvida constituem fontes de informações preciosas para reconstituir a significativa presença pública desses sujeitos na cidade e esta tem sido a forma predominante de sua incorporação às pesquisas históricas. Mas, para além dessa perspectiva, é possível analisar a intensa atuação militante de alguns periódicos em favor da produção e preservação de memórias, às vezes triunfante, às vezes contida, às vezes derrotada. Invertendo o modo de olhar para essa imprensa e procurando formular novas perguntas é possível descobrir intenções e procedimentos de redatores e colaboradores para compor e divulgar informações históricas de associações, congressos, movimentos e militantes, sistematizando e consolidando memórias para com elas construir uma outra história dos trabalhadores na cidade.

Cabe refletir sobre quais eram as motivações dessas folhas populares para "evocar" o passado e quais interpretações buscavam constituir, indagando se essas práticas estavam "de acordo" com o "campo de representações públicas da história". ${ }^{28}$ Há um claro sentido político nos esforços de algumas folhas para criação e manutenção de uma memória potencialmente autônoma por meio do recurso ao passado, cotidianamente atualizado. Nessa direção, importa buscar evidências de qual passado esses sujeitos queriam lembrar e fixar. Os marcos cronológicos e experiências sociais valorizados

\footnotetext{
${ }^{27}$ REGO, Otávio Brandão. Otávio Brandão (depoimento, 1977). Rio de Janeiro: CPDOC, 1993, dat., p. 65. Série de entrevistas concedidas, entre 15 de janeiro e 10 de fevereiro de 1977, aos pesquisadores Maria Cecília Velasco e Cruz e Renato Lessa, do Programa de História Oral do Centro de Pesquisa e Documentação de História Contemporânea do Brasil da Fundação Getúlio Vargas/RJ. Disponível em: http://www.fgv.br/cpdoc/historiaoral/arq/Entrevista213.pdf. Acesso em: 10/09/2015.

${ }^{28}$ Popular Memory Group. Memória popular: teoria, política, método. In: FENELON, Déa Ribeiro; MACIEL, Laura Antunes; ALMEIDA, Paulo Roberto; KHOURY, Yara Aun (org.). Muitas memórias, outras histórias. Tradução de Helen Hudges e Yara A. Khoury. São Paulo: Olho d'Água, 2004, p. 284.
} 
eram diversos ou alternativos ou propunham apenas uma reinterpretação que se colocava ao lado, e em disputa, com versões que se pretendiam únicas e verdadeiras?

As repetidas referências à data 13 de maio nem sempre compartilham a interpretação reafirmada nas comemorações anuais naquele início de século XX, que tentavam atribuir exclusivamente aos brancos e aos grandes homens da pátria a "concessão" da liberdade aos escravos. Para Francisco Juvêncio Sadock de Sá, que assinava com o pseudônimo de François Seul, esta era "a data mais digna e tradicional do socialismo brasileiro", porque marcava uma conquista e a "emancipação do homem de cor", verdadeiro exemplo de que o "homem trabalhador, (...) unido, tudo consegue". ${ }^{29}$ Ele oferece indícios da existência de disputas em torno dos significados desta data e de tentativas para construir e fixar outras interpretações e memórias em torno da liberdade e da abolição, ainda tão próxima. Sem dúvida que uma data como essa não poderia passar despercebida em uma cidade majoritariamente negra e imigrante naquela conjuntura. O testemunho do padeiro João Mattos, sistematizado em 1934, lembra "os tempos idos" da escravidão quando homens "escravizados de fato" trabalhavam "as mesmas 16 e 18 horas consecutivas" nas padarias lado a lado com os "escravizados livres". Ele reivindica para os trabalhadores em padarias um papel ativo e "pioneiro" na luta em prol da liberdade, promovendo fugas de companheiros escravos, porque "os entregadores de pão eram a única classe que tinha facilidade de propagar as ideias antiescravocratas e de insinuar os escravos à Rebeldia por todos os meios". E agiram assim não apenas porque "só tínhamos o gozo do termo livres" e compartilhavam com escravos condições de trabalho muito semelhantes, inclusive castigos físicos, mas também por acreditar que a escravidão "nos impedia o caminho para pugnar pelos nossos ideais". ${ }^{30}$

\footnotetext{
${ }^{29}$ SÁ, Francisco Juvêncio Sadock de. A emancipação do homem de cor. Brazil Operário, n. 2. Rio de Janeiro, ano I, 13 de maio de 1903, p. 1. Sadock de Sá era torneiro mecânico e armeiro, colaborou em diversos jornais, foi secretário do Brazil Operário e um dos fundadores do Partido Operário Independente (1905) e do Círculo de Operários da União (1909) do qual foi diretor por muitos anos. Cf. BATALHA, Cláudio (org.). Dicionário do movimento operário - Rio de Janeiro do século XIX aos anos 1920 - militantes e organizações. São Paulo: Fundação Perseu Abramo, 2009, p. 143-144.

${ }^{30}$ MATTOS, João. Histórico de 1876 a 1912. Eu e todos os companheiros dos idos tempos. Cópia fiel de todos os apontamentos velhos que nesta data inutilizei. 24-9-34. Grifo no original. O autor desse relato era padeiro e abolicionista, ajudou a fundar diversas associações da categoria e, também, o jornal 0 Panificador. O manuscrito, apreendido pela polícia política em 1936, integra uma pasta referente a prisioneiros supostamente ligados ao levante de 1935. Arquivo Público do Estado do Rio de Janeiro, Fundo DPS, d. 30.055, fls. 99 a 117. Esse documento foi
} 
Se "toda atividade política é intrinsecamente um processo de argumentação e definição histórica, [e se] todos os programas políticos envolvem tanto alguma construção do passado quanto do futuro", ${ }^{11}$ a constatação da existência de colunas e seções, em diferentes jornais, destinadas a organizar e difundir memórias das lutas e experiências populares abre um leque de possibilidades a explorar. Em $O$ Echo do Mar, essa preocupação se expressa de forma contraditória, pois há seções que propõem registrar a história das associações de classe de estivadores, marinheiros, remadores e foguistas, das quais o jornal se apresenta como porta voz, mas existe uma outra que visa reunir "Apontamentos para a história da Marinha mercante brasileira" aos cuidados de Eduardo de Lima, redator chefe, e que ocupa toda a parte inferior das páginas de cada edição. Segundo os redatores, a intenção era "trabalhar para manter as glórias marítimas do passado" e para que elas "[servissem] de exemplo para doutrinarem o presente". Entre as "glórias marítimas" lembradas, o auxiliar da redação Antônio dos Reis Leal incluía a batalha naval do Riachuelo, travada em 11 de junho de 1865, uma "gloriosa data" para a Armada brasileira. O fato de esta data ser "escolhida pela Associação de Marinheiros e Remadores e Sociedade União dos Foguistas [para fazer] surgir o seu órgão $O$ Echo do Mar"32 aponta para a força da memória hegemônica no interior - e ao lado - de outras memórias alternativas e dissidentes entre os trabalhadores do mar.

Em quase todos os jornais existiam seções ou textos avulsos que lembravam acontecimentos significativos para o movimento internacional de trabalhadores - 18 de março - início da Comuna de Paris, "o primeiro governo operário"; o $1^{\circ}$ de maio, dia internacional "de luta contra os patrões"; o 11 de novembro, em memória da execução dos "mártires de Chicago"; o 14 de julho, para lembrar a queda da Bastilha; o 13 de outubro, em protesto contra o fuzilamento de Francisco Ferrer y Guardia, educador e anarquista espanhol - entre outras datas que constituíam um calendário coletivo de comemorações. Ao estimular a rememoração desses acontecimentos ano após ano, os jornais procuravam reforçar valores e princípios lastreados em

reproduzido em fac-simile em: DUARTE, Leila. Pão e liberdade: uma história de escravos e livres na virada do século XIX. Rio de Janeiro: Aperj/ Faperj/ Mauad, 2002, p. 62-63.

${ }^{31}$ Popular Memory Group. Memória popular: teoria, política, método, op. cit., p. 287.

32 O Echo do Mar, n. 1. Propriedade das Associações de Marinheiros e Remadores e da União dos Foguistas. Rio de Janeiro, ano I, de 11 de junho de 1909, p. 1. A administração do jornal era constituída pelo redator-chefe Eduardo de Lima, o gerente Timotheo Borges Ferreira e o agente geral, sr. Antônio Gonçalves de Araújo, membros das diretorias das organizações proprietárias do periódico. 
experiências coletivas internacionais, reafirmando o sentido de suas lutas e conquistas também para os brasileiros.

Há inúmeros exemplos de estímulos à celebração de outras datas significativas, como os aniversários de fundação das associações e dos próprios jornais, as fusões e recriações e outras datas especiais dos órgãos de representação desses trabalhadores. Relembradas anualmente, constituíam ocasião para saudar os fundadores, estabelecer um calendário, fixar na memória acontecimentos e pessoas a serem preservados pelo grupo, estimulando um olhar seletivo sobre o passado capaz de alavancar a luta por sua afirmação no presente. Não se trata apenas de relembrar o passado com nostalgia mas, de, por meio dele, reunir forças para olhar à frente, revelando outros horizontes de lutas no presente.

Os manuscritos do padeiro João Mattos, um dos fundadores d'O Panificador, são um testemunho do sentido atribuído por trabalhadores à história. Ao explicar a decisão, em 1934, de organizar "o histórico social" reunindo as memórias compartilhadas com outros companheiros padeiros, ele afirmou atender à advertência dos colegas por "ser o único que ainda na classe sobrevive, dos tempos idos, e estar a par da história por conservar muitos dados escritos daquelas épocas". João Mattos assumiu o trabalho - passando a limpo "apontamentos velhos" realizados entre 1876 e 1912 - como uma tarefa política e militante, por considerar "que a classe é a única herdeira [dessa história], e eu sempre me considerei um seu simples servidor..." ${ }^{33}$ Sua narrativa analisa erros e acertos nos "levantes" (greves) planejados e conduzidos pelos padeiros, relembra as ações para libertar trabalhadores escravizados, avalia possibilidades abortadas, como as duas tentativas de organização da categoria anteriores à criação da Sociedade Cosmopolita Protetora dos Empregados de Padaria, finalmente concretizada em 1898. Com o registro escrito de suas memórias, "um histórico de força e combate", esses padeiros pretendiam impedir que determinadas experiências caíssem no esquecimento e, ao mesmo tempo, estimular seus companheiros a continuarem na luta.

Intenções semelhantes podem ser encontradas em vários jornais que mantinham seções dedicadas a produzir e divulgar informações de associações de diversas categorias, informando questões debatidas em reuniões e assembleias, transcrevendo trechos de atas, relatórios e pequenas notas sobre as mais diversas organizações. Essas iniciativas visavam não só conquistar o

\footnotetext{
33 MATTOS, João. Histórico de 1876 a 1912 ....In: DUARTE, Leila. Pão e liberdade, op. cit., p. 61.
} 
reconhecimento público para as formas de ação e representação coletivas de trabalhadores como, também, preservar a memória de suas iniciativas e realizações, suas lutas e conquistas, destacando a atuação de companheiros no presente e no passado. Ao constituírem uma ampla e intensa rede de comunicação não apenas articulavam diferentes associações, sindicatos e redações de diversos periódicos, como parecem apostar na possibilidade de constituir memórias de suas atividades cotidianas, suas lutas e mobilizações oferecendo aos seus leitores versões alternativas àquelas elaboradas pelos jornais diários.

Cabe aqui indagar sobre os significados dos esforços de alguns periodistas operários para reunir, divulgar e compartilhar informações sobre condições de trabalho e sobrevivência, memórias de lutas e reivindicações, assim como de valores, concepções e expectativas de direitos. Vários jornais abriam espaço em suas páginas para (re)produzir registros que documentassem, rememorassem ou preservassem as ações e conquistas de inúmeros trabalhadores na cidade. Muitas vezes, a iniciativa na produção de registros é individual e os autores avaliam retrospectivamente momentos e acontecimentos considerados decisivos, mas a intenção de enviá-los para publicação faz parte de um esforço comunicativo mais amplo. Lembrar uma greve realizada pela categoria dez anos antes, como fez o carregador José Arias de Castro, membro do Conselho da Sociedade de Resistência dos Trabalhadores em Trapiche e Café, em 1916, significou reafirmá-la como um marco na consolidação da Sociedade e para a afirmação social e política dos trabalhadores nos trapiches de café. Afinal, perguntava ele:

Antes deste movimento, alguém sabia quando nos levantávamos pela manhã para trabalhar e de quantas horas era a jornada? Quem sabia quanto ganhava pelo trabalho que executava? Quem desconhece o modo por que éramos tratados e como o passamos a ser [tratados] depois da greve? (...) senão com o respeito que merecem, ao menos com mais consideração, e sabiam quantas horas trabalhavam e quanto ganhavam; podiam fazer contas e repartir entre si indubitavelmente o fruto do trabalho de empreitada; já não eram despedidos por empregarem regras de matemática a fim de saber quanto ganhavam e não se deixar ludibriar: tais foram os frutos da nossa primeira guerra contra os patrões. ${ }^{34}$

\footnotetext{
${ }^{34} \mathrm{Na}$ Barricada, n. 1. Rio de Janeiro, ano II, 1 de janeiro de 1916. Grifos meus. O autor do texto era o carregador José Arias de Castro, membro do Conselho da Sociedade de Resistência dos Trabalhadores em Trapiche e Café. A greve relembrada por ele ocorreu em agosto de 1906.
} 
Os congressos operários também constituíram momentos memoráveis na história do movimento de trabalhadores, ao mesmo tempo em que ofereciam ocasiões para estimular a vontade de preservar vestígios de um passado operário, desencadeando iniciativas concretas nessa direção. A Confederação Operária Brasileira, responsável pela organização do $2^{\circ}$ Congresso Operário Brasileiro em 1913, propôs na abertura dos trabalhos a 59 associações operárias e quatro jornais ali representados por seus delegados "que em seus movimentos internos não olvidem o que necessário se torne para terem arquivados [e] em boa ordem todos os documentos que se refiram aos fatos mais notáveis de suas classes". ${ }^{35}$ Terminado o Congresso, A Voz do Trabalhador, órgão da Confederação Operária Brasileira, criou uma seção intitulada "Documentos para a História" na qual publicou, entre outubro de 1913 e fevereiro de 1915, os relatórios enviados por onze associações. Todas as narrativas enfatizam os mesmos aspectos definidos como relevantes para compor uma história das associações: as etapas e caminhos da fundação, os responsáveis pela iniciativa, os primeiros membros, as condições de trabalho da categoria, as principais reivindicações e propostas de ação, concluindo com a convocação dos companheiros de classe a se engajar e não abandonar a luta.

Outras vezes, a iniciativa pela publicação de narrativas semelhantes partiu dos responsáveis pelos periódicos, como Voz do Povo, criado como um jornal diário em 1920 pela Federação dos Trabalhadores do Rio de Janeiro, com apoio de ao menos sete sociedades de trabalhadores (têxteis, construção civil, culinários, padeiros, transportes terrestres e marítimos, metalúrgicos entre outras). Com oficinas próprias e um corpo de redatores indicado por essas associações, o jornal propunha estender sua ação "até o interior das fábricas, oficinas e outros centros proletários" recolhendo "notas e informações" divulgadas através da seção "A vida dos trabalhadores". O objetivo era tornar conhecidos "todos os fatos, desde os mais comuns" ocorridos nos "sindicatos, nas oficinas, nas obras e nas fábricas" e, para isso, orientavam seus camaradas a acompanhar "rigorosamente o movimento das suas classes, em todas as suas particularidades", "sem intermitências, ininterruptamente", mas de forma sintética já que o jornal tinha apenas quatro páginas. Além disso, Voz do Povo definia "como ponto essencial [do seu programa], a documentação quanto possível exata e completa, embora resumida", dos movimentos do

\footnotetext{
${ }^{35}$ A Voz do Trabalhador, n. 41. Rio de Janeiro, ano VI, 15 de outubro de 1913, p. 3. Dezoito associações, além da Forj, tomaram parte nesse Congresso representando os trabalhadores da cidade do Rio de Janeiro.
} 
proletariado internacional que "são sempre naturalmente e necessariamente incompletíssimas, deturpadas e atenuadas" pelas informações telegráficas e pela imprensa burguesa. Neste caso, a intenção é clara: buscar as "fontes diretas de informação" para realizar a crítica das notícias publicadas pela imprensa diária e oferecer aos seus leitores outra interpretação "exata e completa, embora resumida" dos acontecimentos. ${ }^{36}$ Por sua postura de denúncia das violências contra trabalhadores - inclusive a aprovação de leis antioperárias - Voz do Povo foi "estrangulado" pela cerrada vigilância da polícia política, pela apreensão de edições e prisão de seus redatores um após outro, até que a Forj foi obrigada a suspender sua publicação. ${ }^{37}$

Mais uma vez, estamos diante de uma "política voluntarista da lembrança"38 na qual os apelos à história emergem com um sentido claro: relembrar lutas e conquistas como estratégia política para mobilizar para ação, articulando passado e presente.

\section{Inscrevendo memórias na cidade}

Em uma cidade empenhada em remodelar sistematicamente suas ruas e praças através de projetos de "embelezamento" e "saneamento", que arrasou morros, "erradicou" cortiços e hábitos condenáveis, e apagou as marcas de sua fundação e do passado colonial, é fundamental atentar para iniciativas do movimento operário carioca no início do século XX destinadas a construir a sua própria memória, a produzir a visibilidade de sua atuação e preservar os vestígios do seu passado na cidade. Considerando que a memória desempenha papel crucial no interior dos mecanismos de poder e se explicita nas disputas em torno de quais experiências sociais são dignas de integrar, com legitimidade, um passado comum, acompanho diferentes esforços de trabalhadores para afirmação de sua presença e memórias no espaço público da cidade. O formato e os recursos simbólicos usados por

\footnotetext{
${ }^{36}$ Voz do Povo, n. 2. Órgão da Federação dos Trabalhadores do Rio de Janeiro e do proletariado em geral, ano I de 6 de fevereiro de 1920. Jornal diário, dirigido inicialmente pelo gráfico e anarquista Carlos Dias, substituído por Afonso Schmidt, tinha redação e administração na rua da Constituição, 12.

37 SODRÉ, Nelson Werneck. História da imprensa no Brasil. Rio de Janeiro: Ed. Mauad, 1999, p. 321. DIAS, Everardo. História das lutas sociais no Brasil, op. cit., p. 98.

${ }^{38}$ RÉBÉRIOUX, Madeleine. Lugares da memória operária. In: CUNHA, Maria Clementina Pereira. (org.) O direito à memória. Patrimônio histórico e cidadania. São Paulo: Prefeitura do Município de São Paulo/DPH, 1992, p. 47.
} 
trabalhadores em ações massivas de militância que reuniam diversas associações e se desdobravam pelas ruas em meetings, préstitos ou passeatas, comícios, festivais e outras formas rituais são bem estudados e conhecidos. São exemplares dessa "linguagem do movimento operário" o uso de carros decorados com símbolos e retratos de trabalhadores mortos, cartazes de protesto, pavilhão social e estandartes de sociedades e outros adereços, assim como o caráter de culto à memória - dos companheiros mortos em lutas passadas, de datas compartilhadas -, cultivada com um claro sentido de criação de tradições comuns, quase sempre associadas e solidárias aos trabalhadores ao redor do mundo. ${ }^{39}$

As festas dos aniversários de criação de associações e jornais seguiam um ritual semelhante ao das comemorações iniciais do Primeiro de Maio e consistiam em préstitos que percorriam as "principais ruas" do centro da cidade, partindo dos endereços das suas sedes sociais. Acompanhados de bandas de música, conduzindo estandartes e símbolos das associações, além de cartazes com reivindicações e protestos, todo um arsenal de símbolos e formas rituais de expressão foi criado e mobilizado nessas marchas: paradas estratégicas para discursos, vivas e saudações aos companheiros de outras associações e jornais, homenagens aos estandartes, hinos e cânticos operários.

Em geral, os préstitos cruzavam as estreitas ruas do centro onde estavam instaladas as sociedades e jornais de trabalhadores finalizando com comícios em largos ou jardins públicos como os largos de São Domingos e de São Francisco de Paula, "o tradicional ponto da manifestação do sentimento popular", ${ }^{40}$ a praça Marechal Floriano, o campo de Santana e o campo de São Cristóvão. Alguns desses lugares ficaram conhecidos como ruas e praças "guerreiras, revoltosas", "ruas oradoras, ruas de meeting" como "o largo do Capim que assim foi sempre, o largo de São Francisco"41 e dão a medida da força da inscrição desses símbolos da luta dos trabalhadores na cidade.

\footnotetext{
${ }_{39}$ Ver, por exemplo: KOCHER, Bernardo. Luto-luta - o primeiro de maio no Rio de Janeiro: 1890-1940. Dissertação de mestrado em História, UFF, Niterói, 1987; ARRÊAS, Luciana Barbosa. A redenção dos operários: o primeiro de maio no Rio de Janeiro durante a República Velha. Dissertação de mestrado em História, Unicamp, Campinas, 1996; BATALHA, Cláudio; SILVA, Fernando Teixeira; FORTES, Alexandre (org.). Culturas de classe: identidade e diversidade na formação do operariado. Campinas: Editora da Unicamp, 2004, p. 95-100.

${ }^{40}$ Folha do Dia, de 17 de março de 1913.

${ }^{41}$ BARRETO, Paulo. [João do Rio]. A rua. In: Idem. A alma encantadora das ruas. São Paulo: Cia. das Letras, 1997, p. 56-60. Originalmente uma conferência, foi publicada na Gazeta de Notícias em 29 de outubro de 1905.
} 
Everardo Dias, aos 79 anos de idade relembrava as comemorações de $1^{\mathrm{o}}$ de maio das quais participou "sessenta anos passados":

"Que diferença com as manifestações proletárias de outrora! Que diferença com os desfiles dos trabalhadores organizados! (...) Não iam em procissão, como os atuais desfiles exibicionistas comemorativos de $1^{\circ}$ de maio, rufando tambores em cadência de escoteiros, marcando passo, fitinhas a tiracolo com as cores nacionais (...). Não. Não era assim que se comemorava o $1^{\circ}$ de maio - essa data trágica, que lembra tanta luta, (...) que recorda patíbulos na praça pública, que lembra mártires e barricadas para a conquista das oito horas..."42

Mas são menos conhecidos os esforços realizados por associações e periódicos para constituir certos espaços públicos e privados como os seus "lugares de memória", 43 assim como os meios utilizados para legitimação do passado vivido evidenciando as estratégias de inscrição de vestígios materiais da sua experiência histórica na cidade do Rio de Janeiro. Mas através de testemunhos dos próprios trabalhadores e o seu investimento no registro de lugares de pertencimento coletivo - as sedes das associações de resistência e das redações de jornais operários - é possível identificar os espaços da cidade presentes em seus imaginários, lugares evocados e lembrados e, também, os investimentos para materializar sua história na cidade. Persigo os "lugares simbólicos, promovidos a símbolos por um processo de memorização consciente e militante, tornados simbólicos pela vontade de vencer o esquecimento no qual se mergulha não só a vida cotidiana operária, mas também a luta dos dominados". São aqueles "lugares patrimoniais (...) cuja significação é negada pelo poder e pela sociedade", mas foi insistentemente "reafirmada pela vontade propagandística das associações operárias". ${ }^{4}$

Um inventário das memórias dos trabalhadores cariocas nos leva para os espaços coletivos onde se constituíram práticas associativas e laços de solidariedade de classe e que podem ser apreendidos a partir dos endereços das redações e escritórios de jornais e órgãos de propaganda, das sedes sociais de associações, ligas, uniões, sociedades e partidos, de tipografias e

\footnotetext{
${ }^{42}$ DIAS, Everardo. História das lutas sociais no Brasil, op. cit., p. 73.

${ }^{43}$ Lugares de "reconhecimento e pertencimento de grupo" ou "onde palpita ainda algo de uma vida simbólica", como afirma Nora e inclui "espaços de solidariedade, [e] de sociabilidade" como nos lembra Rébérioux porque "o horizonte [da memória operária] jamais se limitou ao espaço do trabalho". NORA, Pierre. Entre memória e história. A problemática dos lugares. Revista Projeto História, n. 10, São Paulo, PUC/SP, dez. 1993, p. 7-98; e RÉBÉRIOUX, Madeleine. Lugares da memória operária, op. cit., p. 53.

${ }^{44}$ RÉBÉRIOUX, Madeleine. Lugares da memória operária, op. cit., p. 53.
} 
gráficas, clubes, bibliotecas, escolas e teatros, assim como os principais trajetos e espaços públicos de comemorações e/ou protesto na cidade. Misturada a essa sociabilidade de caráter classista que se constituía no cotidiano dessas organizações, articulavam-se outras formas associativas - clubes, salões, sociedades - de vários tipos (carnavalescas, literárias, dramáticas, musicais), que remetem para a constituição de uma cultura popular múltipla e profundamente enraizada na cidade do Rio de Janeiro. ${ }^{45}$

Mapear os endereços de redações de periódicos e sedes de associações de trabalhadores, mantidos às vezes ao longo de décadas, nos indicam caminhos pelos quais trabalhadores constituíram espaços públicos e inscreveram suas práticas sociais na cidade. A busca pelos lugares significativos para a organização e visibilidade dos trabalhadores nos leva ao trecho "relativamente prestigioso" da cidade entre a Candelária e o antigo campo de Santana (praça da República), onde se concentrava um número significativo de jornais e associações de trabalhadores, desde meados do século XIX, principalmente entre as ruas dos Andradas, Uruguaiana ( $A$ Voz do Povo, O Combate), Gonçalves Dias (O Tipógrafo), e ruas transversais no perímetro definido pelas ruas de São Pedro e São José. A concentração mais antiga e numericamente expressiva às vezes com quatro ou mais redações em uma mesma rua - ficava nas ruas da Misericórdia nº 44 e 10 (O Componedor e A Voz do Chauffeur), Constituição, General Câmara e nas próprias São Pedro n 96 e 102 (Brasil Operário e O Combate) e São José, seguidas pelas ruas Senhor dos Passos, 7 de Setembro nº 7, 32 e 35 (O Operário; O Independente e outro O Operário), Buenos Aires, a antiga rua do Hospício ( $A$ Voz do Trabalhador e $O$ Baluarte) e em torno da praça Tiradentes com a instalação, desde 1906, do Centro dos Operários Marmoristas e a redação de seu jornal $O$ Marmorista, no número 71, endereço compartilhado, a partir de 1923, com a Federação Operária do Rio de Janeiro.

Os deslocamentos d'A Voz do Trabalhador, órgão da Confederação Operária Brasileira, por três sedes entre 1908 e 1909 dá uma dimensão das dificuldades para manter em funcionamento as redações desses periódicos e, também, a obstinação em permanecer na antiga rua do Hospício. Durante o ano de 1910, pelo menos, A Voz do Trabalhador compartilhou o sobrado de $n^{\circ} 166$

\footnotetext{
${ }^{45}$ Sobre as transformações nas comemorações militantes e a incorporação de práticas culturais populares e aspectos de espetáculos de massa ver: HARDMAN, Francisco Foot. Nem pátria, nem patrão! Memória operária, cultura e literatura no Brasil. $3^{a}$ edição. São Paulo, Ed. da Unesp, 2002. Para uma análise das práticas culturais nas organizações operárias e de seus entrecruzamentos com a cultura popular urbana no Rio de Janeiro ver BATALHA, Cláudio. Cultura associativa no Rio de Janeiro da Primeira República, op. cit.
} 
com a administração d'O Baluarte, órgão dos operários chapeleiros. No início de 1913, nova mudança deslocaria a administração d'A Voz do Trabalhador desta vez para a rua General Câmara, 335.

Acompanhar o esforço organizativo dos empregados em padaria e os deslocamentos de suas sedes sociais e redações de seu jornal pelas ruas do Rio de Janeiro permite visualizar a extrema mobilidade das instituições criadas por trabalhadores e indica as dificuldades que precisavam ser contornadas para seu enraizamento na cidade. A primeira associação dos padeiros foi concebida como "Bloco de Combate dos Empregados de Padaria" em uma reunião realizada "no chafariz (...) no Largo do Paço, em 5 de abril de 1880". A sede foi instalada na rua da Conceição, 28 e funcionou clandestinamente por cerca de um ano sob a fachada de um "centro de dança", até a prisão de um sócio que revelou o local das reuniões mensais. A segunda tentativa de organização resultou na criação da "Sociedade Cooperativa dos Empregados de Padaria no Brasil" durante reunião com cerca de "300 companheiros" no Liceu de Artes e Ofícios, convocada pela imprensa e folhetos entregues em padarias. Cumpridas as exigências legais, conseguiram alugar uma sala no $1^{\circ}$ andar do prédio à rua de São Pedro, 244 e nela instalaram, em junho de 1890, sua sede social, que sobreviveu apenas um ano. Oito anos depois, "em uma reunião num botequim", três companheiros de militância combinaram fundar nova entidade de classe, a "Sociedade Cosmopolita Protetora dos Empregados de Padaria", concretizada em novembro de 1898. O endereço escolhido para a instalação da sede foi uma sala alugada no mesmo número da rua de São Pedro "por ser histórica" para a categoria, uma referência à memória da segunda experiência de organização autônoma dos padeiros. Apesar do simbolismo do lugar, em 1900, a sede social da Sociedade já havia sido transferida para a rua da Alfândega, 194 onde também funcionava a redação de seu jornal $O$ Panificador, recém criado, onde permaneceram até 1902, quando a sociedade se desfez. No mesmo ano, localizamos notícias de reorganização da sociedade, agora como "Cosmopolita Protectora dos Empregados em Padaria", instalada em novo endereço na rua Camerino, 143, sobrado. Nessa ocasião, seus militantes enfrentavam a concorrência de colegas influenciados por "uns patrões maquiavélicos" que até dinheiro teriam oferecido para a criação de outra associação, a "Liga Federal dos Empregados em Padaria do Rio de Janeiro" em Botafogo. ${ }^{46}$

\footnotetext{
${ }^{46}$ MATTOS, João. Histórico de 1876 a 1912 ... In: DUARTE, Leila. Pão e liberdade, op. cit., p. 76. Para informações sobre deslocamentos das sedes, consultar os indicadores operários publicados
} 
Dois "indicadores operários", publicados por jornais distintos com intervalo de 18 anos entre ambos, permitem comparar os endereços de associações e sociedades de resistência e acompanhar as permanências e seus deslocamentos na cidade constituída por trabalhadores. O indicador organizado e publicado pela Gazeta Operária, em 1902, confirma a concentração de associações e jornais nas ruas centrais já indicadas. Já a listagem publicada por A Voz do Povo em fevereiro de 1920 mostra que a cidade constituída pelos trabalhadores havia se ampliado significativamente ao redor e além da praça da República, distribuindo-se por ruas como a General Câmara (n. 333: Aliança dos T. em Marcenaria e Classes Anexas, Ass. dos Trabalhadores em Carrinhos de Mão, Aliança dos T. do Comercio e Industria; A Voz do Trabalhador, desde 1913), Senador Pompeu (União Geral dos Metalúrgicos, Centro dos Operários em Massas Alimentícias, União dos Empregados Municipais e União dos Operários em Usinas de Refinação), a Barão de São Félix (Soc. Protetora dos Condutores de Veículos a Mão e União dos E. em Construção de Veículos, União Geral da Construção Civil (UGCC) ${ }^{47}$ e do Senado (a Cônica Subversiva (1918) no no 215, no n 54 o Archote (1908), além da União dos Motoristas em Guindastes Elétricos).

A própria praça da República, que na década de 1920 já não constituía "o espaço da política" e nem o "centro de diversão e lazer", ${ }^{48}$ sediava agora os trabalhadores em pedreiras, barbeiros e lustradores, todos compartilhando uma sede no número 58, além dos operários em obras de viação e da construção civil em endereços próximos ao redor da praça. Essa região, densamente habitada pela população pobre - tanto em cortiços quanto nos morros vizinhos -, estava cercada por oficinas, fábricas e fabriquetas de vários produtos, comércio, armazéns, botequins e restaurantes, além de inúmeras sedes sociais de uniões e sociedades. Ruas como a Senador Pompeu, Barão de São Félix (sede da Gazeta Operária, 1902-06), da Misericórdia ou Camerino, que nos "tempos da colônia e do império" possuíam palacetes que serviram

pela Gazeta Operária, n. 2, Rio de Janeiro, ano I, de 5 de outubro de 1902, p. 4 e $A$ Voz do Povo, n. 2. Órgão da Federação dos Trabalhadores do Rio de Janeiro e do proletariado em geral. Rio de Janeiro, ano I, de 6 de fevereiro de 1920, p. 3.

${ }^{47}$ Na rua Barão de São Félix moravam vários militantes como Florentino de Carvalho, Domingos Passos e Orlando Simoneck. Cf. RAMOS, Renato \& SAMIS, Alexandre. Domingos Passos: $O$ "Bakunin brasileiro". Rio de Janeiro: Federação Anarquista do Rio de Janeiro - FARJ, 2004.

${ }^{48}$ BATALHA, Cláudio. A geografia associativa: associações operárias, protesto e espaço urbano no Rio de Janeiro da Primeira República. In: AZEVEDO, Elciene et al. (org.). Trabalhadores na cidade: cotidiano e cultura no Rio de Janeiro e em São Paulo, séculos XIX e XX. Campinas: Ed. da Unicamp, 2009, p. 251. 
de residências "aos nobres", ${ }^{49}$ desde o final do século XIX já haviam sido subdivididas e transformadas em habitações coletivas. Talvez por isso, elas fossem acessíveis para trabalhadores em ofícios como cocheiros e condutores de veículos, cigarreiros, operários da construção civil, escultores em madeira, trabalhadores em carvão, que lá mantinham suas sedes sociais e as redações de seus jornais.

A manutenção de sedes, alugadas ou de propriedade das sociedades ou redações de periódicos, era um objetivo perseguido por inúmeras categorias. Mas, ao contrário dos trabalhadores portenhos e uruguaios que estabeleciam as redações de seus periódicos nos bairros com maior concentração fabril,,$^{50}$ os trabalhadores cariocas optavam por instalar suas sedes sociais no centro da cidade, em ruas e avenidas importantes, muitas vezes ao lado das redações dos grandes jornais diários, de sociedades literárias e teatros reconhecidos e frequentados por intelectuais e burgueses. O inventário dos endereços das sedes sociais e redações dos periódicos de trabalhadores no Rio de Janeiro permite avaliar os esforços de muitas categorias para dotar suas ações de visibilidade e respeitabilidade públicas.

A escolha dos endereços mais prestigiosos na cidade para instalação de associações e jornais por parte de algumas categorias profissionais indica sem dúvida uma estratégia deliberada para melhorar sua "representação pública". ${ }^{51}$ Ao estabelecer suas sedes sociais em vias alargadas e renomeadas, ou recém abertas, durante a reforma urbana - como a av. Passos (Associação Graphica) ou as ruas Senhor dos Passos (União das Costureiras e União dos Alfaiates), Mem de Sá (Ass. Profissional Têxtil), Camerino (Ass. de Resistência dos Trabalhadores em Carvão Mineral e União dos Trabalhadores do Cais do Porto), Gomes Freire, mal. Floriano (ex-rua Larga) e Visconde do Rio Branco -, procuravam afirmar sua importância e respeitabilidade no centro comercial e político da capital federal.

Essa estratégia, no entanto, não pode obscurecer um processo de hierarquização e diferenciação geográfica de trabalhadores com menores recursos financeiros ou dificuldades para cumprir exigências formais para a locação de imóveis. Aos calafates e pintores, instalados na rua Santo Cristo, ou aos

\footnotetext{
${ }^{49}$ BACKHEUSER, Everardo. Habitações populares. Relatório apresentado ao exmo sr. dr. J. J. Seabra, ministro da Justiça e Negócios Interiores. Rio de Janeiro: Imprensa Nacional, 1906, p. 108.

${ }^{50}$ LOBATO, Mirta Zaida. La prensa obrera. Buenos Aires y Montevideo - 1890-1958. Buenos Aires: Edhasa, 2009, p. 54.

${ }^{51}$ BATALHA, Cláudio. A geografia associativa: associações operárias, protesto e espaço urbano no Rio de Janeiro da Primeira República, op. cit., p. 261.
} 
ferroviários e trabalhadores em vidrarias, que compartilhavam o número 11 na travessa Souza Valente, em São Cristóvão, parece ser possível apenas o aluguel de salas em ruas mais distantes do centro. A lógica da escolha dos endereços parece indicar, também, vínculos com alguns pedaços da cidade em função de especificidades étnicas ou da dinâmica particular de sua organização do trabalho. Este parece ser o caso das entidades que representavam as turmas de trabalhadores ligados aos armazéns, trapiches e transporte de café - conhecidas como "um reduto negro" e nacional ${ }^{52}$-, os estivadores e outros ligados ao trabalho marítimo - como o Centro Protetor dos Catraeiros (rua do Acre), as associações de Marinheiros e Remadores, a União dos Foguistas, a redação e administração do seu órgão Echo do Mar (compartilhando uma sala na rua da Saúde, 167) - para os quais era fundamental manter-se nos bairros da Saúde e Gamboa, próximos ao cais do porto. Por isso mesmo, marinheiros, remadores e foguistas da Marinha Mercante consideravam "o problema da aquisição dum edifício próprio para esta associação (...) como um dos passos gigantescos no nosso meio social". A realização desta "obra brilhante" serviria também para que os marinheiros vissem "tremular o majestoso pendão, símbolo do nosso socialismo, em edifício próprio". 53

Por meio desse inventário é possível visualizar o mapa da cidade que trabalhadores desenharam com sua ação coletiva pública, evidenciando os territórios constituídos por meio de sua organização e militância. Uma primeira constatação é a extrema mobilidade das sedes sociais e redações, indicando em parte a instabilidade financeira e organizacional de algumas instituições trabalhadoras. Além das dificuldades previsíveis para o pagamento de aluguéis, móveis e equipamentos, mais premente para trabalhadores menos qualificados e com baixos salários, é preciso considerar o peso das exigências de registros prévios na polícia, e a necessidade de autorização para a criação e funcionamento de associações, redações de jornais e para a instalação e manutenção de suas sedes sociais. Na maior parte da história brasileira, a liberdade de associação e reunião constituiu-se, para os trabalhadores, um direito a ser conquistado, continuamente reivindicado desde as primeiras greves e mobilizações.

\footnotetext{
52 VELASCO e CRUZ, Maria Cecília. Tradições negras na formação de um sindicato: Sociedade de Resistência dos Trabalhadores em Trapiche e Café. Rio de Janeiro, 1905-1930. Afro-Ásia, n. 24, Salvador: UFBA, 2000, p. 270.

53 LEAL, Antônio dos Reis. Aos marinheiros. Echo do Mar, n. 4, Rio de Janeiro, ano I, 30 de julho de 1909, p. 2. O autor era diretor da Associação dos Marinheiros e Remadores e um dos auxiliares de redação do Echo.
} 
Outro aspecto a ressaltar é o número significativo de entidades que não conseguiam manter uma sede - às vezes por longos períodos de tempo - e, por essa razão, compartilhavam com outras sociedades ou jornais, andares ou salas alugadas em pequenos sobrados. Essa era a situação das entidades dos trabalhadores em marcenaria, do comércio e indústria, e dos trabalhadores em carrinhos de mão, todos funcionando, em 1920, no número 333 da rua General Câmara; situação idêntica à dos vassoureiros, trabalhadores em fábricas de tabaco e tinturarias, instalados no número 22 da rua da Constituição. Outras vezes, as sedes sociais de entidades de classe funcionavam nos mesmos cortiços onde moravam alguns dos seus membros. A Sociedade Beneficente de Marceneiros, Carpinteiros e Artes Correlatas do Rio de Janeiro, constituída em março de 1875 com sede na rua do Príncipe, n. 37, em setembro já registrava 157 associados. Desse total, 58 moravam na mesma rua do Príncipe e destes:

16 moravam na casa que servia como sede provisória da associação, no ํㅡ 37, e outros 26 [sócios] no no 42 . Pode-se supor que se tratava de uma habitação coletiva, uma casa de cômodos que abrigava um grande número de marceneiros e carpinteiros que, além de morarem juntos, sentiram-se dispostos a defender seus interesses coletivos de forma organizada. ${ }^{54}$

A maioria das redações dos jornais editados por trabalhadores funcionava em salas das próprias associações ou em fundos de padarias, lojas, botequins ou nas tipografias onde eram impressos, utilizavam equipamentos de impressão descartados ou em processo de substituição pelos grandes periódicos, mas teimavam em se manter apesar de enormes dificuldades financeiras e de inúmeras restrições ao seu livre funcionamento e circulação. São frequentes as denúncias de perseguições policiais e prisões de diretores e redatores, rotulados como "agitadores", as apreensões de edições, as depredações de redações e oficinas levando ao fechamento de inúmeros jornais.

Acima de tudo, é significativa a importância atribuída a esses lugares de solidariedade e sociabilidade na memória operária militante e o lugar que ocupavam em seus imaginários. As sedes sociais de uniões e sociedades, mas, principalmente, as redações de seus jornais constituíam-se como centros de informações, agência de notícias sobre o mundo do trabalho (quadro de vagas e oferta de empregos, condições de trabalho) das organizações e seus pe-

\footnotetext{
${ }^{54}$ PEREIRA, Ronaldo. Associações de classe, profissionais e beneficentes do Rio de Janeiro (1860-1889). Disponível em: http://www.dhi.uem.br/publicacoesdhi/dialogos/volume01/vol03_atg6.htm. Acesso em: 20/10/2015.
} 
riódicos (convocatórias de reuniões e assembleias, pontos de venda avulsa e distribuição de jornais) ou da vida social dos próprios trabalhadores (avisos de festas, nascimentos e casamentos, lazer), recepção e circulação de recados e correspondências para associados, além de abrigar reuniões, conferências e bibliotecas. Nas datas comemorativas ou durante os movimentos grevistas, particularmente, multidões acorriam às redações dos jornais em busca de informações sobre negociações com patrões e polícia, avanços e recuos no movimento, ou para acompanhar os debates e participar de assembleias que extravasavam dos salões para as ruas.

Em autobiografias ou nos raros testemunhos orais de trabalhadores, militantes ou não, eles rememoram os seus lugares de memória em função da intensidade das experiências vividas no passado. Em testemunho produzido cinco décadas após as experiências relembradas, Otávio Brandão elabora um mapa dos lugares associados às lutas e memórias coletivas:

Os sindicatos ficavam perto da rua Larga, em lugares assim. (...) Então, o trabalhador saía da fábrica, da oficina, entrava no sindicato e ali recebia manifestos, recebia explicações, pagava mensalidade e aquilo tudo. (...). Tínhamos o jornal $A$ Nação, que era diário naquele tempo. Quando eu passo ali em frente do Teatro Municipal, olho aqueles arranha-céus. Era ali a redação. Um velho edifício. Foi derrubado. (...)

O edifício ainda está lá: é na rua da Constituição, esquina da praça da República. Lá num cantinho nós instalamos o Bloco Operário e Camponês. Antes foi na rua do Lavradio, mas ninguém apareceu. Todo dia fazíamos propaganda pela esquina, não conseguíamos nada, nada; mas quando nos mudamos para a praça da República, (...) aí começou a aparecer gente. Aquela massa das fábricas que ia pela rua Larga, por aquela zona toda, dava meia-volta e entrava na sede do Bloco.

Logo [que cheguei ao Rio, em 1919] dias depois, fui para o Sindicato da Construção Civil. Chamava União dos Operários em Construção Civil, era na praça da República, ali pertinho da Central do Brasil. $O$ edifício foi derrubado, era no primeiro andar.

Jornal Spartacus, 1919; A Voz do Povo, 1920. Era diário, A Voz do Povo. Jornal [A Voz do Povo] era órgão oficial da Federação. E militantes da Federação escreviam lá, na Voz do Povo. (...) Houve um tempo que ela tinha sede ali, no mesmo edifício, rua da Constituição. Às vezes eu passo, olho: "Eu te conheço, velho edifício". Constituição 11, mais ou menos. Rua do Constituição, perto da praça Tiradentes..$^{55}$

São as ações cotidianas ou os eventos significativos compartilhados greves, comícios, atos de fundação, celebrações - associados às instituições e aos lugares que orientam essa operação de memória, elaborada e institu-

\footnotetext{
${ }_{55}$ REGO, Otávio Brandão. Otávio Brandão (depoimento, 1977), op. cit., p. 23-65. Grifos meus.
} 
ída como um patrimônio comum a todos os trabalhadores. As sedes sociais das associações são lembradas tanto pelo seu funcionamento cotidiano com reuniões e assembleias quanto pela convivência que promoviam durante a encenação de peças teatrais, conferências e comemorações, tecendo e cultivando laços de união e solidariedade. Edifícios e ruas despertam lembranças de antigas greves, dos comitês de sindicato nas fábricas e da capacidade de mobilização dos trabalhadores:

A União dos Operários em Construção Civil, na praça da República; Sindicato dos Sapateiros, praça da República; Centro Cosmopolita, rua do Senado 215, eram os garçons e cozinheiros; Associação dos Marinheiros e Remadores, rua Conselheiro Zacarias lá na Saúde; Carvão e Mineral. (...) Imagine você que o sindicato dos tecelões se chamava União dos Operários em Fábricas de Tecidos (...) Quando passo pela rua Acre, olho, e está lá ainda o edifício. O sindicato era no primeiro andar. Eu olho, paro, assim, e um mundo de recordações me vem à cabeça".56

Quanto às redações de jornais, além de servirem às tarefas de produção dos periódicos, funcionavam como pontos fixos para a distribuição de exemplares aos membros da associação ou do sindicato, para a arrecadação de fundos e venda avulsa de exemplares. Mas, acima de tudo, cumpriam um papel fundamental na organização dos trabalhadores porque reuniam e faziam circular informes sobre reuniões, greves e paralisações, mobilizando-os em torno de campanhas e causas diversas. O que caracteriza a memória operária, portanto, é o esforço por situar e reconstituir lugares - inclusive os desaparecidos - associados ao cotidiano da militância compartilhada ou de eventos significativos para a "massa das fábricas", como "lugares que foram ocupados por outros e servem de espelho para outras memórias", pois "só existe passado proletário quando compartilhado".57

Algumas ruas são lembradas em função da representatividade das organizações nelas instaladas, do número de associações que nelas se concentrava ou, ainda, pela reunião de escolas, bibliotecas, teatros ou salões junto às sedes de sociedades e/ou jornais, que intensificava o fluxo de trabalhadores nestes lugares. Não é por acaso que ruas como a da Constituição são lembradas, ainda hoje, em textos e roteiros destinados a preservar a me-

\footnotetext{
${ }^{56}$ REGO, Otávio Brandão. Otávio Brandão (depoimento, 1977), op. cit., p. 20. Grifos meus.

57 RÉBÉRIOUX, Madeleine. Lugares da memória operária. In: CUNHA, Maria Clementina Pereira. (org.). O direito à memória. Patrimônio histórico e cidadania, op. cit., p. 55.
} 
mória anarquista no Rio de Janeiro, em função de diferentes organizações anarquistas que, ao longo do tempo, nela foram instalados:

No número 14 funcionou a livraria de Lírio de Rezende, poeta anarquista (...), a primeira especializada em literatura anarquista; no número 47 (esquina com avenida Gomes Freire), (...) no prédio de três andares que abrigava o Centro Internacional dos Pintores, em meados de 1904 os anarquistas iniciaram sua experiência da Universidade Popular de Ensino Livre. E foi ali, já nos primeiros anos do século XX, que funcionavam, nos números 30 e 32, as instalações do Centro Galego. (...) [que sediou] de 15 a 20 de abril de 1906 o I Congresso Operário Brasileiro, momento histórico para o proletariado brasileiro então em formação. ${ }^{58}$

Acompanhei estratégias desenvolvidas por associações e periódicos operários para preservação da memória e inscrição de sua presença e visibilidade na cidade, indagando em que medida eles serviram para ancorar e sustentar a visibilidade pública das ações e mobilizações coletivas de trabalhadores na conjuntura histórica analisada. Apesar da intensa presença de trabalhadores no centro da cidade do Rio de Janeiro, de sua capacidade para imprimir as marcas de suas ações e experiências e diferenciar as ruas e largos "de meeting" em contraposição àquelas de "calma alegria burguesa", como diferencia João do Rio, as memórias dessas ações não foram incorporadas aos relatos memorialísticos nem à história da cidade.

Tampouco as edificações ocupadas por suas instituições foram objeto de políticas de preservação e as poucas sobreviventes continuam à margem do rol de bens tombados como patrimônio histórico e cultural dos cariocas. As ações e marcas construídas por décadas de experiência social cotidiana e/ou militante de trabalhadores na cidade não se constituem como referências de passado com as quais os moradores constroem laços de pertencimento com sua cidade no presente.

Só podemos compreender esse apagamento se considerarmos que "a memória é também um campo minado pelas lutas sociais: um campo de luta política, de verdades que se batem, (...) e constitui uma das formas mais poderosas e sutis de dominação e legitimação do poder" ${ }^{\prime 59}$ As ações organi-

\footnotetext{
${ }^{58}$ LOPES, Milton. Memória anarquista do Centro Galego do Rio de Janeiro. Federação Anarquista do Rio de Janeiro/ Núcleo de Pesquisa Marques da Costa. Disponível em: http://marquesdacosta. wordpress.com/textos/memoria-anarquista-do-centro-galego-do-rio-de-janeiro-milton-lopes/. Acesso em: 20/09/2015.

59 PUC/SP. Programa de Pós-Graduação em História. Cultura, trabalho e cidade: Muitas memórias, outras histórias. São Paulo: PUC-SP, Projeto Procad/Capes, 2000, mimeo, p. 9.
} 
zadas por trabalhadores, duramente reprimidas no passado porque "subversivas" ou "perigosas", continuam a ser silenciadas e negadas no presente pela maioria dos guias turísticos, pelo ensino oficial de história e pelas ações de preservação do patrimônio histórico.

Não é coincidência, também, que os inúmeros planos e intervenções para "embelezamento" ou "renovação" urbanas, realizadas ao longo da história da cidade, tenham definido como seus alvos preferenciais as áreas tradicionalmente ocupadas por trabalhadores. O movimento contínuo de demolição e reconstrução dos suportes materiais dessa memória bloqueia lembranças e desorganiza as referências, produzindo “a invisibilidade e inaudibilidade dos dissidentes pelo apagamento dos sinais e vestígios de suas memórias e histórias". ${ }^{60}$ Talvez por essa razão, durante seu depoimento ao CPDOC, Octávio Brandão repita diversas vezes: "O edifício ainda está lá" como se a sobrevivência de um prédio ajudasse a sustentar sua experiência ou atestasse a veracidade de suas lembranças.

\section{Referências bibliográficas}

BATALHA, Cláudio. A geografia associativa: associações operárias, protesto e espaço urbano no Rio de Janeiro da Primeira República. In: AZEVEDO, Elciene et al. (org.). Trabalhadores na cidade: cotidiano e cultura no Rio de Janeiro e em São Paulo, séculos XIX e XX. Campinas: Ed. da Unicamp, 2009.

Cultura associativa no Rio de Janeiro da Primeira República. In: BATALHA, Cláudio; SILVA, Fernando Teixeira da; FORTES, Alexandre (org.). Culturas de classe: identidade e diversidade na formação do operariado. Campinas: Editora da Unicamp, 2004.

CRUZ, Heloisa de Faria. São Paulo em papel e tinta: periodismo e vida urbana - 1890-1915. São Paulo: Educ/ Fapesp/ Arquivo do Estado de São Paulo/ Imprensa Oficial de São Paulo, 2000.

FERREIRA, Maria Nazareth. A imprensa operária no Brasil. Petrópolis: Vozes, 1978. Imprensa operária no Brasil. São Paulo: Editora Ática, 1988.

HARDMAN, Francisco Foot. Imprensa operária, espaço público e resistência: notas de leitura. In: Idem. Nem pátria, nem patrão. $3^{\text {a }}$ edição. São Paulo: Ed. da Unesp, 2002.

KOCHER, Bernardo; LOBO, Eulalia Maria Lahmeyer; MARTINS, Ismênia de Lima. Guia dos jornais operários do Rio de Janeiro. Rio de Janeiro: Universidade Federal Fluminense, 1988.

\footnotetext{
${ }^{60}$ PUC/SP. Programa de Pós-Graduação em História. Cultura, trabalho e cidade: Muitas memórias, outras histórias, op. cit., p. 10.
} 
LOBATO, Mirta Zaida. La prensa obrera. Buenos Aires y Montevideo - 1890-1958. Buenos Aires: Edhasa, 2009.

MACIEL, Laura Antunes. Imprensa de trabalhadores, feita por trabalhadores, para trabalhadores? História E Perspectivas, n. 39, Uberlândia: UFU, 2008.

Cultura letrada, intelectuais e memórias populares. In: ENGEL, Magali; CORRÊA, Maria Letícia; SANTOS, Ricardo dos (org.). Os intelectuais e a cidade: séculos XIX e XX. Rio de Janeiro: Contra Capa, 2012.

MENDONÇA, Leandro Clímaco. Nas margens: experiências de suburbanos com periodismo no Rio de Janeiro, 1880-1920. Niterói: Ed da UFF, 2014.

PAOLI, Maria Célia. Trabalhadores e cidadania: Experiência do mundo público na história do Brasil moderno. Estudos Avançados, vol. 3, n. 7, São Paulo: Instituto de Estudos Avançados da Universidade de São Paulo, set-dez 1989.

PEREIRA, Ronaldo. Associações de classe, profissionais e beneficentes do Rio de Janeiro (1860-1889). Disponível em: http://www.dhi.uem.br/publicacoesdhi/dialogos/ volume01/vol03_atg6.htm. Acesso em: 20/10/2015.

Popular Memory Group. Memória popular: teoria, política, método. In: FENELON, Déa Ribeiro; MACIEL, Laura Antunes; ALMEIDA, Paulo Roberto; KHOURY, Yara Aun (org.). Muitas memórias, outras histórias. Tradução de Helen Hudges e Yara A. Khoury. São Paulo: Olho d'Água, 2004.

PUC/SP. Programa de Pós-Graduação em História. Cultura, trabalho e cidade: Muitas memórias, outras histórias. São Paulo: PUC-SP, Projeto Procad/Capes, 2000, mimeo.

RÉBÉRIOUX, Madeleine. Lugares da memória operária. In: CUNHA, Maria Clementina Pereira (org.). O direito à memória. Patrimônio histórico e cidadania. São Paulo: Prefeitura do Município de São Paulo/DPH, 1992.

SODRÉ, Nelson Werneck. História da imprensa no Brasil. Rio de Janeiro: Ed. Mauad, 1999.

Recebido: 08/01/2016 - Aprovado: 31/10/2016 